\title{
Role of Traditional Ethnobotanical Knowledge and Indigenous Communities in Achieving Sustainable Development Goals
}

\author{
Ajay Kumar ${ }^{1, *}$, Sushil Kumar ${ }^{2}$, Komal $^{3}$, Nirala Ramchiary ${ }^{4}$ and Pardeep Singh ${ }^{5}$ \\ 1 Department of Plant Science, School of Biological Sciences, Central University of Kerala, \\ Periye, Kasaragod 671316, Kerala, India \\ 2 Department of Botany, Government Degree College, Kishtwar, Kishtwar 182204, \\ Jammu and Kashmir, India; sushilthakur863@gmail.com \\ 3 Department of English, Government Degree College, Bani, Kathua 184206, \\ Jammu and Kashmir, India; komalkanthalia108@gmail.com \\ 4 Translational and Evolutionary Genomics Laboratory, School of Life Sciences, \\ Jawaharlal Nehru University, New Delhi 110067, India; nramchiary@jnu.ac.in \\ 5 Department of Environmental Science, PGDAV College, University of Delhi, \\ New Delhi 110065, India; psingh@pgdav.du.ac.in \\ * Correspondence: ajay@cukerala.ac.in
}

Citation: Kumar, A.; Kumar, S.; Komal; Ramchiary, N.; Singh, P. Role of Traditional Ethnobotanical Knowledge and Indigenous Communities in Achieving Sustainable Development Goals. Sustainability 2021, 13, 3062. https://doi.org/10.3390/su13063062

Academic Editor: Emanuele Radicett

Received: 19 January 2021

Accepted: 4 March 2021

Published: 11 March 2021

Publisher's Note: MDPI stays neutral with regard to jurisdictional claims in published maps and institutional affiliations.

Copyright: (c) 2021 by the authors. Licensee MDPI, Basel, Switzerland. This article is an open access article distributed under the terms and conditions of the Creative Commons Attribution (CC BY) license (https:// creativecommons.org/licenses/by/ $4.0 /)$.

\begin{abstract}
The sustainable development goals (SDGs) are a set of 17 goals with 169 targets. The Agenda 2030 of the United Nations envisages a holistic approach to achieve these goals by focusing on humankind and the planet. In this review, we analyzed the scientific literature and technical reports of international bodies such as the United Nations and Food and Agriculture Organization relating to traditional ethnobotanical knowledge (TEK). The literature on TEK was mapped with the targets of the SDGs to determine the role of traditional knowledge in the realization of selected goals and targets. Our extensive and systematic reviewing of available literatures suggests that, of the 17 goals, at least seven goals are associated with TEK. To achieve these seven goals, a thorough understanding is required to disentangle the intricacies involving TEK, indigenous people holding TEK, and their future role in achieving the SDGs. Our review points towards the role of TEK in achieving goals linked to poverty, health and wellbeing, responsible consumption and production, climate action, life on land, and partnerships. In summary, we argue that achieving the intended outcomes of the SDGs and the targets requires concerted efforts of all relevant stakeholders, including indigenous communities, common citizens, scientists, policy makers, and world leaders.
\end{abstract}

Keywords: sustainable development goals; ethnobotany; human health; poverty; traditional knowledge; sustainable agriculture

\section{Introduction}

The United Nations General Assembly in its 70th meeting on 25 September 2015 adopted a resolution "transforming our world: the 2030 agenda for sustainable development" [1]. Its member countries adopted 17 set of goals called the sustainable development goals (SDGs) to end poverty, protect the planet, and ensure prosperity for all. Each goal has certain targets to be achieved by 2030. Sustainable development goals are an extension of millennium development goals (MDGs) and part of a new sustainable development agenda to complete what MDGs did not achieve [2]. For the goals to be realized, everyone needs to do their part, including governments, the private sector, and civil society. The Agenda 21 of the Rio Earth Summit in 1992 [3] where the concept of sustainable development emerged, advocated a pivotal role for indigenous people and other local communities in the management of environment and sustainable development because of their traditional knowledge and associated practices [4]. The official UN document of 2015 (transforming our world: the 2030 agenda for sustainable development) did not explicitly explain the role of ethnobotanists and traditional ethnobotanical knowledge (TEK) in achieving these 
sustainable development goals. Apart from the role of different countries and various stakeholders mentioned in the document in achieving the goals and targets, we advocate and reiterate a similar role for indigenous communities by recognizing and supporting their identity, cultures, customs, practices, and interests and by enabling their effective and active participation in the realization of sustainable development goals, including the goals that were mentioned in Principle 22 of the 1992 Rio Declaration on the Environment and Development [3]. It was reaffirmed that traditional ethnobotanical knowledge, ethnobotanists, and people's participation can significantly contribute towards achieving the sustainable development goals by 2030 and beyond.

People have a long history of using plants for various purposes such as for food, medicine, shelter, decoration, construction, and clothing [5]. The usage of plants for various purposes by indigenous and local communities comprises traditional ethnobotanical knowledge, which is not well documented by indigenous people, but has been orally and vertically transmitted from generation to generation [6]. However, ethnobotanists have played an important role in unraveling and documenting these plant-people interactions and unlocked the knowledge by conducting various types of interviews and surveys $[7,8]$. Besides these, archeological, paleontological, and archaeogenetic evidence has also recently been used to determine plant-people interactions from prehistoric times [9-11]. Though the records on the consumption of plants by humans in the prehistoric times are scarce, recently it was discovered that people in South Africa used leaves of Cryptocarya woodii for the construction of bedding 77,000 years ago, and the identity of the plants used was established using modern archaeogenetic tools [12]. This plant is still used by the people living in the area of its recovery, and it has now been established that this plant is toxic to mosquitoes because of its larvicidal properties [12]. The recovery of starch granules from the surfaces of at least 105,000 years old stone tools from Mozambique suggests that early humans consumed grass seeds [9]. The discipline of ethnobotany works at the intersection of plants-people at one end and science at the other end; therefore, ethnobotanists can act as a bridge between them [13]. Tuxill and Nabhan [14] have suggested that ethnobotany can act as useful vehicle and process of development. The outcomes of the interactions between the plants and people as deciphered by ethnobotanists holds enormous potential to solve some of the issues that the world faces today. The common global challenges we face today are ending poverty, achieving zero hunger, improving the nutritional status of the people, promoting sustainable agriculture, improving the health status of the people, providing affordable health care services, and combating climate change $[15,16]$. Therefore, in the present review article, we identified seven sustainable development goals towards which the traditional ethnobotanical knowledge can contribute significantly. These are SDG (1) no poverty, (2) zero hunger, (3) good health and wellbeing, (12) responsible consumption and production, (13) climate action, (15) life on land, and (17) partnerships for the goals. In the following sections, a brief background of major challenges and the potential roles of ethnobotany in overcoming these challenges to achieve the SDG by 2030 are presented (Figure 1). 


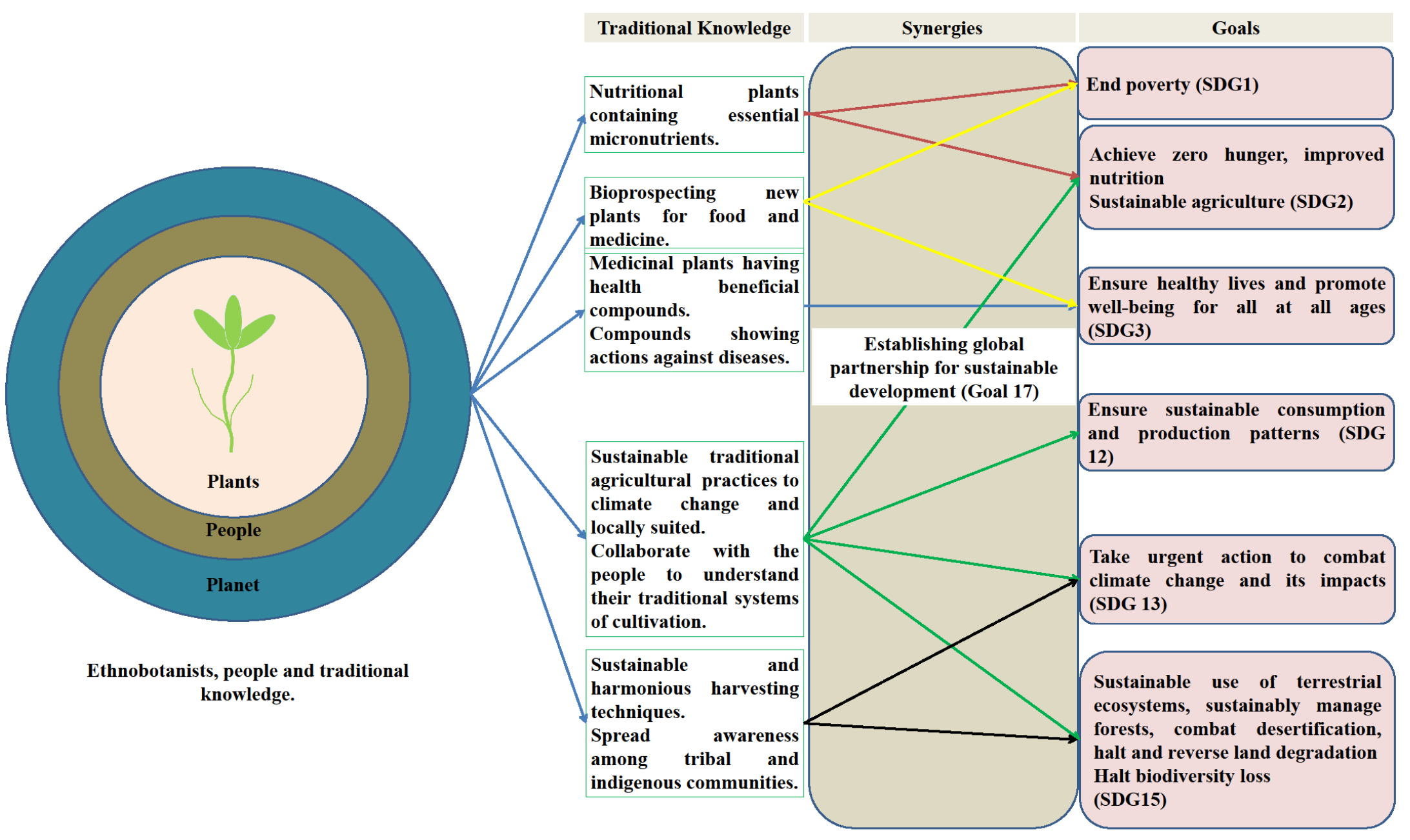

Figure 1. A schematic representation highlighting the potential roles of ethnobotanists towards achieving seven sustainable goals and targets. 


\section{Methodology}

To study the role of ethnobotanical knowledge in the realization of sustainable development goals, we searched available literature and information available on the subject [17]. Various reports and documents of the international bodies such as the UN and FAO were studied to understand the sustainable development goals and the targets envisaged under it. We conducted an extensive literature survey to find out papers and reports related to traditional knowledge to link with the sustainable development goals. The research question in the present study was to know whether there were any goals and targets related to ethnobotanical knowledge and whether ethnobotanical knowledge could help in achieving them. After a thorough study, we have identified seven goals related to ethnobotanical knowledge which are SDG 1 (no poverty), 2 (zero hunger), 3 (food health and wellbeing), 12 (responsible consumption and production), 13 (climate action), 15 (life on land), and 17 (partnerships for the goals). The seven goals and targets thereunder are abridged into four broad areas (Table 1) as few goals have overlapping/common targets, and then the gaps or problems in those broad areas are identified. For example, SDG 2 is common for broad area 1 (poverty-hunger-malnutrition) and broad area 2 (desertification, land degradation, and sustainable agriculture). Similarly, SDG 15 is repeated for broad area 2 and 4 (ensuring sustainable consumption-production and reversal of biodiversity loss). The goal 17 (SDG 17) refers to establishing partnerships and synergies among various stakeholders. Therefore, the need of partnerships to achieve different goals or outcomes is discussed in the broad areas. Following this criteria, various papers related to ethnobotanical studies were analyzed to fill the gaps or to solve the problems. Furthermore, various terms relating to sustainable development goals such as "traditional knowledge", "ethnobotanical knowledge", "traditional agricultural knowledge", "traditional ecological knowledge", "food security", "abiotic stresses", "climate change", "end hunger", "food security", "medicinal plants", "sustainable agriculture", "climate resilience" and "ethnobotanical knowledge" and various combinations of key terms were searched from various databases such as PubMed, Google Scholar, Web of Science, AGRICOLA, and Scopus $[17,18]$. The terms were searched either individually or in multiple combinations. The electronic search queries generated more than 3000 papers from various databases. We manually analyzed and removed the duplicates and only 105 articles including reports and websites were included for writing this review. For the survey of various reports relating to sustainable development goals, a simple Google search was used or the website of the organizations were directly visited.

Table 1. The identified four broad areas and the sustainable development goals linked with them.

\begin{tabular}{|c|c|}
\hline Broad Area & Goals Linked to the Broad Area \\
\hline Poverty-hunger-malnutrition & $\begin{array}{l}\text { SDG 1: End poverty. } \\
\text { SDG 2: Achieve zero hunger and improve nutritional status } \\
\text { of the public. }\end{array}$ \\
\hline $\begin{array}{l}\text { Desertification, land degradation, } \\
\text { and sustainable agriculture }\end{array}$ & $\begin{array}{l}\text { SDG 2: Achieve sustainable food production systems. } \\
\text { SDG 15: Protect, restore, and promote sustainable use of terrestrial } \\
\text { ecosystems; sustainably manage forests; combat desertification; and } \\
\text { halt and reverse land degradation and halt biodiversity loss. }\end{array}$ \\
\hline Health and wellbeing of the people & SDG 3: Ensure healthy lives and promote well-being for all at all ages. \\
\hline $\begin{array}{l}\text { Ensuring sustainable } \\
\text { consumption-production reversal of } \\
\text { biodiversity loss }\end{array}$ & $\begin{array}{l}\text { Goal 12: Ensure sustainable consumption and production patterns. } \\
\text { Goal 13: Take urgent action to combat climate change and its impacts. } \\
\text { SDG 15: Protect, restore, and promote sustainable use of terrestrial } \\
\text { ecosystems; sustainably manage forests; combat desertification; and } \\
\text { halt and reverse land degradation and halt biodiversity loss. }\end{array}$ \\
\hline $\begin{array}{l}\text { Partnerships (important for } \\
\text { achieving all the goals) }\end{array}$ & $\begin{array}{l}\text { SDG 17: Revitalize the global partnership for } \\
\text { sustainable development. }\end{array}$ \\
\hline
\end{tabular}




\section{Results and Discussion}

\subsection{Poverty-Hunger-Malnutrition Conundrum and the Role of Wild Food Plants}

The ever-increasing human population projections indicate an increase in the number of consumers and demand for goods and services [19]. The Agenda 2030 seeks to end poverty (SDG1), achieve zero hunger, and improve nutritional status of the public (SDG2). Poverty, hunger, and nutrition are three interlinked issues with cause and effect relationships which need to be addressed systematically in an integrated manner [20]. Targeting poverty alone may help to achieve zero hunger, but unless people have access to nutritious food, it may not deliver the expected result [21]. Therefore, the initiatives for alleviating poverty must be coupled with addressing the issues related to diet, malnutrition, and undernutrition. Approximately one billion of the poorest people of the world remain undernourished today, and the Food and Agriculture Organization (FAO) estimated that we will need to increase food production by $70 \%$ to feed the 9.1 billion people by 2050 [22]. These data suggest the gravity of challenges the world is facing to ensure food security for all.

As per the FAO [23], food security has four main dimensions: (1) physical availability of food (supply of food), (2) economic and physical access to food, (3) food utilization, and (4) the stability of the other three dimensions over time (Figure 2). The ethnobotanical consumption of wild vegetables and food plants by indigenous communities are in congruence with the above four dimensions as locally grown wild vegetables can help increase the supply of food thereby maintaining demand-supply equilibrium (as described in Figure 2). Since the wild food plants are collected and consumed locally by people, the change in the prices of the market foods may not affect the economic access to it. Besides this, the plants are locally grown, adapted to particular local environmental conditions, resilient to climate change, and are suitable to the local agro-climatic conditions [24]. Therefore, researchers have now emphasized the urgent need to diversify and expand the food basket of the people under unpredictable climatic conditions [25], and in this scenario wild food plants if adopted in mainstream diet are the best option to achieve this goal [26,27]. Several study groups also reported the importance and wide usage of wild food plants in various countries such as India [7,8,27,28], Ethiopia [29,30], China [31], Indonesia [32], Greece [33], and Italy [34,35], to name a few. Since the locally grown plants are rich in vitamins and micronutrients, they can help in reducing diet related malnutrition considerably [32,36]. Ethnobotanists have already generated immense amounts of data on the use of wild plants for food. A search on Google Scholar titled "wild plants as food" shows $1,220,000$ results (within the years 2000-2020). All these results suggest that many wild plants under consumption by various indigenous communities have already been documented. Therefore, the present challenges of food insecurity necessitate the mainstreaming of wild food plants, their formal addition into the existing food basket of the public by scientifically validating the nutritional composition, the study and development of the mode of their multiplication/reproduction, and the life cycle-related requirements for their germination and cultivation. To achieve this, multidisciplinary approaches and experts in agronomy, plant science, phytochemistry, dietetics, and modern analytical approaches for nutritional profiling need to be employed. Furthermore, potential health effects also need to be understood as some plants may have the presence of harmful compounds which may exert negative side effects on humans. Combining multidisciplinary approaches along with the clues obtained from ethnobotanical data on wild plants for consumption as fruits and vegetables can provide alternative options and aid in diversifying the food basket of the people [25]. The issue of food security can be catered by popularizing and mass propagation of the locally grown plants especially in the developing countries in Africa and Asia. This can further reduce the dependency of people on only a few crop plants available for their nutritional purposes. In the long run, apart from the role of wild food plants in the diversification of food basket, they can also act as valuable genetic resources for the crop improvement programs as some of the food plants consumed indigenously are the wild relatives of the domesticated crops plants currently grown/consumed. 


\section{Wild and Traditional Food Plants}

- Grown and consumed locally.

- Suited to local agro-ecosystems.

- Easily available

- Availability not affected by global physical disruptions.
- Less exposed to external shocks.

- Least affected by general inflation.

- Increase in prices do not affect their availability.

- Relatively cheaper.
Physical availability of food (supply of food).
2 Economic and physical access to food.

\section{Four Dimensions for Ensuring} Food Security (FAO)

Food utilization.

Stability of the three dimensions over time.

- Rich in micronutrients and important phytochemicals essential for human health and nutrition.

- Locally adapted to consumption.

- Easily bioassimilated.
- Resilient to stresses.

- Perform better under unfavourable conditions.

- Wild and traditional food plants contribute to stability of all the three dimensions.

Figure 2. The role of Wild and Traditional Food Plants in FAO's four dimensions for ensuring global food security. 


\subsection{Overuse of Chemicals in Agriculture, Desertification, Land Degradation and the Need for Sustainable Agriculture}

The increased demand for nutritious, safe, and healthy food for the burgeoning human population and the promise to maintain biodiversity and other natural resources are posing a major challenge to agriculture that is already threatened by climate change and excessive use of chemical fertilizers and pesticides [25]. The excessive use of fertilizers has rendered soils unfit for agricultural purposes. Its long-term use has increased the salinity of the soils and reduced the total land available for cultivation of crops [37]. This problem of soil degradation is severe in tropics and subtropics, and it has led to decrease in the soil ecosystem services by $60 \%$ in the 60 years from 1950 to 2010 [38]. It has been reported that nearly 500 million hectares (Mha) of the land is affected due to the soil degradation in the tropics [39], and globally $33 \%$ of the total land is affected due to land degradation $[40,41]$. Besides affecting agronomic production, soil degradation can also slow down the economic growth of developing countries which are majorly dependent on agriculture [42]. The use of chemical pesticides has a deteriorating effect on the non-target beneficial insects such as honey bees [43-45]. Pesticides can affect bee populations directly by causing mortality and by altering their behaviour through sublethal effects. Sublethal pesticides also interfere with brood development and shorten the life cycle of adults [46]. An unusual phenomenon of the disappearance of bees from beehives was observed in the US in 2006 which was termed as colony collapse disorder (CCD) [43,47]. It has been established that many factors might contribute to CCD but pesticides play a synergistic role in this disorder $[43,48,49]$. Interestingly, organic beekeepers did not face such CCD-like situations [50]. Considering the importance of bees in pollination of the food crops, the increased use of pesticides can lead to reduced food production endangering our food security [50]. The fertilizer and pesticide runoff have also adversely affected quality of surface and groundwater [51]. Thus total land available for cultivation is reduced due to its degradation caused by various activities such as water and wind erosion, salinity, sodicity, alkalinity, reduction in soil fertility, and urban expansion [52]. The increase in productivity of land available using sustainable practices, conservation of the remaining land resources, and reclamation of the degraded land are some of the challenges in land use and sustainable agriculture [53-55].

Besides achieving zero hunger and improved nutrition, SDG2 also seeks to achieve sustainable food production systems (sustainable agriculture) through the implementation of resilient agricultural practices that increase productivity by maintaining the health of the ecosystems [56]. Through the intimate association with the plants and agriculture related activities, people have gained tremendous knowledge on the various aspects of agriculture and crops plants [57]. The knowledge ranges from the soil types, season of sowing a particular crop, the water and nutrient requirements, and other conditions which promote or limit crop productivity [58,59]. The knowledge also pertains to the diseases caused by pathogens and attack by pests and their management strategies [60,61]. The ethnobotanical knowledge is vast, not uniformly distributed, and locally suited as per the environmental conditions and the availability of particular crops $[62,63]$. In addition to the lack of proper documentation, researchers have suggested that increased modernization may have led to the loss of this knowledge in many places [64]. Turner and Turner [65] have ascribed some other reasons to this loss which include dynamism and changing knowledge systems, loss of indigenous languages, lack of time and opportunities for cultural practices, urbanization of indigenous people, globalization, and industrialization. These challenges in the world agriculture calls for the immediate attention not only to protect the knowledge base of the communities involved in ethnobotany in active sense but also to revive where it is dormant [24]. Rockstrom et al. [66] have stressed the necessity of identifying environmental conditions that enable prosperous human development and set limits for the planet to remain in that state. The study further suggests that the Holocene epoch provides a reference point when the naturally occurring environmental change was within the limits of earth's regulatory capacity and it helped our ancestors to develop agriculture and modern societies to prosper [66]. Therefore, efforts must be taken to 
understand, preserve, and promote traditional agricultural knowledge locked with the indigenous communities encompassing wide range of domains of agriculture ranging from types of soils, diseases, environmental conditions, to the management of diseases, interventions required in the soils for disease prevention, irrigation, the types of genotypes, and their selection for a particular soil type [63]. Literature on linking of various domains on traditional agricultural knowledge is scarce [67], and it is advisable to take up studies that consider linking across domains of traditional agricultural knowledge. The knowledge of traditional and sustainable agricultural practices must be strengthened in the interest of the public and the planet; therefore, a greater role of traditional knowledge experts and the communities holding this knowledge is suggested [68-70]. Greater public participation, more funding, and scientific research must be promoted. Sustainable agricultural practices need to be followed which involve the minimal use of chemical fertilizers and pesticides. The reduced use of chemicals and promotion of sustainable agriculture will help combat climate change (SDG 13). Sustainable agriculture and climate resilient cultivation practices will further arrest and reverse land degradation caused by the rampant use of chemical fertilizers. This would also halt biodiversity loss especially the bees and other pollinator species, which is very important for crop diversification (SDG 15).

\subsection{Health and Wellbeing of the People: Blend of Traditional Knowledge and Modern Science}

Of the various uses of plants, medicinal plants used for human health and wellbeing are the most important because of the presence of specialized metabolites in those plants (SM's) [71]. Specialized metabolites with medicinal properties are non-uniformly distributed in certain families of plants, and these plants act as natural chemical factories for the production of SM's [72]. The SM's have promising health promoting effects and are an important source of many of the present-day drugs [73]. It has been suggested that medicinal plants play a major role in the primary health care of nearly 80 percent of people living in the developing countries [74]. Not only in the developing countries, but natural products and medications derived from them also contribute significantly to the health care systems of the remaining 20 percent of the people residing in developed countries [75]. Interestingly, of the 25 best-selling pharmaceutical drugs, 12 are natural products derived from the plants [76,77]. Ethnobotanists have significantly contributed to the discovery of numerous medicines such as artemisinin (from Artemisia annua L.), aspirin (from Filipendula ulmaria (L.) Maxim.), ephedrine (Ephedra spp.) codeine and papaverine (from Papaver somniferum L.), colchicine (from Colchicum autumnale L.), taxol (from Taxus brevifolia Nutt.), digoxin and digitoxin (from Digitalis purpurea L.), capsaicin (from Capsicum spp.), and tetrahydrocannabinol and cannabidiol (from Cannabis sativa L.), to name a few [71,78-80]. The importance of the discovery of Artemisinin was recognized when Tu Youyou, a Chinese scientist, was awarded Nobel prize in 2015 [81]. Further, a search on Google Scholar titled "wild plants as medicine" shows 216,000 results (between the years 2000-2020).

Indigenous and tribal communities use thousands of plants for medicinal purposes, many of them are not even botanically named, and many drugs of the plant origin are waiting to be discovered by modern science [82-84]. The famous anthropologist David Maybury-Lewis had emphasized the role of tribal communities in assisting the discovery of more and more medicinal plants which are used by them for medicinal purposes [85]. Ethnobotanists can expedite the identification process of probable medicinally valuable plants, and it is suggested that instead of undertaking random screening expeditions, clues and leads can be derived from the ethnobotanical knowledge that can ease the task of bioprospecting of the plants [86]. Garnatje et al. [6,71] suggested the term "ethnobotanical convergence" for the similar uses of plants included in the same node of a phylogeny. Although the term "ethnobotanical convergence" was criticized by Hawkins and TeixidorToneu [87], it is nevertheless believed that linking of new technologies with the traditional ethnobotanical knowledge can expedite the process of target-based drug discovery. Linking ethnobotany with other disciplines such as phytochemistry, pharmacology, pharmacognosy, 
and molecular biology can aid in the identification and screening of important plants for their promising role in treating diseases [88]. Furthermore, approaches such as genomics and omics can also be employed to identify the genes underlying the (specialized) metabolites present in the plants characterized by high throughput metabolomics approaches such as gas chromatography-mass spectrometry (GCMS), liquid chromatography-mass spectrometry (LCMS) and nuclear magnetic resonance spectroscopy (NMR) $[89,90]$. The proper identification, utilization, and conservation of medicinal plants can assist in providing better alternative healthcare services in rural areas, especially in developing countries [91,92]. Furthermore, a number of wild medicinal and aromatic plants are highly valuable, and a significant proportion of the people consume them for medicinal purposes [93]. The scarcity of better health care systems ensuring healthy lives and promoting wellbeing of the people at all ages (SDG 3) in the developing countries of Asia and Africa underpins the importance of ethnomedicinal plants [91,92]. The upward trend of dependency on plantbased medicines, especially in the past few decades, suggests that the role of plant-based drugs will continue to grow in the coming years which may put pressure on the available medicinal plant resources. With the growing burden of diseases coupled with issues such as population growth and climate change, the discovery of plant-based medicines needs to be hastened using leads from indigenous communities in collaboration with experts from multiple disciplines.

\subsection{Ensuring Sustainable Consumption-Production Patterns Would Halt Biodiversity Loss}

Harvesting practices of wild plants are generally invasive and are destructive to the naturally occurring wild vegetables and medicinal plants which may pose serious threat to these important plants and if kept unchecked sometimes may lead to the extinction of some of the important species [94]. According to the World Wildlife Fund and International Union for Conservation of Nature, approx. 50,000 to 80,000 species of flowering plants are currently being used for medicinal purposes worldwide [95]. Nearly 15,000 of them are threatened with extinction due to excessive exploitation and habitat destruction [96]. The issues related to harvesting coupled with over-exploitation, over usage, and climate change necessitates the need for change in collection and consumption patterns. The collection and consumption patterns need to be congruous with the self-regeneration potential of wild genetic resources; therefore, ethnobotanists can play important roles in the conservation of genetic resources by providing feedback to the communities relying on collection and consumption of medicinal plants [97]. Several researchers have demonstrated the importance of ethnobotany in the conservation and management of natural resources. For example, Phillips and Gentry $[98,99]$ have shown that the number of uses of a plant and its popularity can be used to indirectly access the harvesting pressure on a species and the roles of the communities involved in its usage. Bussmann [75] has also highlighted the role of ethnobotany in the conservation of biodiversity [75]. Ethnobotany can help conserve biodiversity by evolving achievable models for natural resource use and effective management that can be integrated into decision and policy making [100]. A case study from Southern Ecuador has stressed the need to include interdisciplinary approaches for the conservation of ethnomedicinal plants to prevent them from over harvesting. To reduce the pressure on wild plants, alternative methods can be adopted to propagate them. For example, the most popular herbal tea of Southern Ecuador is "Horchata" which consists of more than 30 medicinal herbs, and the harvesting of them directly from the wild may endanger their survival. Nowadays, these 30 ingredients are organically produced by local farmers in small managed gardens instead of directly collecting from the wild, thereby reducing the pressure on the wild populations [75]. Peters, Alexiades, and Laird [101] have suggested the need of imparting skills to the indigenous communities for the better management of the tropical forests. This would reduce the dependency on the external inputs and create a skilled workforce of local communities. Experts from various disciplines such as forestry, ecology, ethnobotany, economics, and anthropology can intervene and play a crucial role in managing the forests and other resources. Skills and knowledge of the best 
practices such as how to grow, harvest, and consume wild vegetables and other resources in a sustainable manner (SDG 12) would also play a synergistic role in strengthening the community management of the valuable resources. Awareness programs at larger scale must also be integrated while training selected members of local indigenous communities to highlight negative effects of destructive harvesting practices. The sustainable consumption production patterns would further halt biodiversity loss (SDG15). Besides this, the conservation initiatives can be undertaken along with the help of conservation scientists, geneticists, and people's participation. Integration of traditional knowledge into ecological research for biodiversity conservation involving local communities holds the potential towards sustainable development [102], and it must be recognized and promoted [103,104].

\section{Conclusions}

The role of ethnobotanical knowledge, indigenous communities, and ethnobotanists has to be recognized on an urgent basis in realizing sustainable development goals. An international collaboration consortium deriving people from various countries and various fields can be established to reap the benefits of traditional ethnobotanical knowledge to alleviate poverty, end hunger, provide better healthcare facilities, combat climate change, and conserve biodiversity and solve biodiversity related issues. Digitization and the creation of universal databases of the usage of plants for various purposes as a global common can be initiated to disseminate information with regard to ethnobotanically important plants and the knowledge associated with it. The modern scientists can use these clues to further establish scientific reasoning, for example, to investigate which compound may be responsible for treating a particular disease; what the nutritional profile of a plant is; whether it can be recommended as a source of nutrition, and if yes, how much is sufficient. Thus, we call for strengthening ethnobotanical studies, and sufficient funding needs to be channeled for promoting research in this field in order to meet SDGs. This can be concluded with a quote by Dr. Margaret Chan (former Director General of WHO), "The two systems of traditional and Western medicine need not clash. Within the context of primary health care, they can blend together in a beneficial harmony, using the best features of each system, and compensating for certain weaknesses in each. This is not something that will happen all by itself. Deliberate policy decisions have to be made. But it can be done successfully" [105]. This holds true not only for the traditional medicines but also for other domains of traditional knowledge such as food plants, sustainable agriculture, biodiversity conservation, and climate change. Traditional knowledge can be supplemented with the modern advancements in science. This integrated approach involving a blend of traditional knowledge and modern advancements in science can contribute to achieving the SDGs if planned and implemented properly. These integrated approaches are in consonance with the SDG 17 (revitalize the global partnership for sustainable development) which emphasizes the importance of global partnership for achieving the rest of the 16 goals. We believe that ethnobotany research groups and societies from various parts of the world must initiate collaborations and partnerships among themselves and with other fields in a cross-disciplinary manner for realizing the sustainable development goals in the greater interest of people and the planet.

Author Contributions: A.K., S.K. and N.R.: conceptualization, methodology, writing一original draft preparation, review and editing, visualization; K., and P.S.: writing-original draft preparation, review and editing. All authors have read and agreed to the published version of the manuscript.

Funding: This research received no external funding.

Institutional Review Board Statement: Not applicable.

Informed Consent Statement: Not applicable.

Data Availability Statement: All data generated or analyzed during this study are included in this publication.

Acknowledgments: We gratefully acknowledge the continuing support by Central University of Kerala and Jawaharlal Nehru University, New Delhi. 
Conflicts of Interest: The authors declare that they have no competing interests.

\section{References}

1. UN General Assembly. Transforming our World: The 2030 Agenda for Sustainable Development; Report No. A/RES/70/1. Available online: http:/ / www.un.org/ga/search/view_doc.asp?symbol=A/RES/70/1\&Lang=E (accessed on 16 May 2020).

2. International Council for Science and International Social Science Council. Review of Targets for the Sustainable Development Goals: The Science Perspective. Available online: https:/ / www.icsu.org/publications/review-of-targets-for-the-sustainabledevelopment-goals-the-science-perspective-2015 (accessed on 13 April 2020).

3. United Nations General Assembly. Report of the United Nations Conference on Environment and Development (Rio de Janeiro, 3-14 June 1992). 1992. Available online: http:/ / www.un.org/documents/ga/conf151/aconf15126-1annex1.htm (accessed on 17 May 2020).

4. Kimerling, J. Rio+10: Indigenous Peoples, Transnational Corporations, and Sustainable Development in Amazonia; CUNY Academic Works. 2002. Available online: https:/ /academicworks.cuny.edu/cl_pubs/252 (accessed on 28 June 2020).

5. Balick, M.J. Transforming Ethnobotany for the New Millennium. Ann. Mo. Bot. Gard. 1996, 83, 58. [CrossRef]

6. Garnatje, T.; Peñuelas, J.; Vallès, J. Reaffirming 'Ethnobotanical Convergence'. Trends Plant Sci. 2017, 22, 640-641. [CrossRef]

7. Saha, D.; Sundriyal, M.; Sundriyal, R.C. Diversity of Food Composition and Nutritive Analysis of Edible Wild Plants in a Multi-Ethnic Tribal Land, Northeast India: An Important Facet for Food Supply. Indian J. Tradit. Knowl. 2014, 13, 698-705.

8. Chauhan, S.H.; Yadav, S.; Takahashi, T.; Łuczaj, Ł.; D’Cruz, L.; Okada, K. Consumption Patterns of Wild Edibles by the Vasavas: A Case Study from Gujarat, India. J. Ethnobiol. Ethnomed. 2018, 14, 57. [CrossRef] [PubMed]

9. Mercader, J. Mozambican Grass Seed Consumption during the Middle Stone Age. Science 2009, 326, 1680-1683. [CrossRef] [PubMed]

10. Liu, L.; Bestel, S.; Shi, J.; Song, Y.; Chen, X. Paleolithic Human Exploitation of Plant Foods during the Last Glacial Maximum in North China. Proc. Natl. Acad. Sci. USA 2013, 110, 5380-5385. [CrossRef]

11. Allaby, R.G.; Kistler, L.; Gutaker, R.M.; Ware, R.; Kitchen, J.L.; Smith, O.; Clarke, A.C. Archaeogenomic Insights into the Adaptation of Plants to the Human Environment: Pushing Plant-Hominin Co-Evolution Back to the Pliocene. J. Hum. Evol. 2015, 79, 150-157. [CrossRef]

12. Wadley, L.; Sievers, C.; Bamford, M.; Goldberg, P.; Berna, F.; Miller, C. Middle Stone Age Bedding Construction and Settlement Patterns at Sibudu, South Africa. Science 2011, 334, 1388-1391. [CrossRef] [PubMed]

13. Alexiades, M. Ethnobotany in the Third Millennium: Expectations and Unresolved Issues. Delpinoa 2003, 45, 15-28.

14. Tuxill, J.D.; Nabhan, G.P. People, Plants, and Protected Areas: A Guide to in Situ Management; Earthscan: London, UK, 2001; ISBN 9781853837821.

15. Food and Agriculture Organization of the United Nations. Food and Agriculture: Key to Achieving the 2030 Agenda for Sustainable Development. 2009. Available online: http://www.fao.org/policy-support/tools-and-publications/resourcesdetails/en/c/422261/ (accessed on 17 February 2021).

16. The Sustainable Development Goals Report. Available online: https://unstats.un.org/sdgs/report/2017/ (accessed on 17 February 2021).

17. Snyder, H. Literature Review as a Research Methodology: An Overview and Guidelines. J. Bus. Res. 2019, 104, 333-339. [CrossRef]

18. Kugley, S.; Wade, A.; Thomas, J.; Mahood, Q.; Jørgensen, A.K.; Hammerstrøm, K.; Sathe, N. Searching for Studies: A Guide to Information Retrieval for Campbell Systematic Reviews. Campbell Syst. Rev. 2017, 13, 1-73. [CrossRef]

19. Newson, R.S.; Lion, R.; Crawford, R.J.; Curtis, V.; Elmadfa, I.; Feunekes, G.I.; Hicks, C.; van Liere, M.; Lowe, C.; Meijer, G.W.; et al Behaviour Change for Better Health: Nutrition, Hygiene and Sustainability. BMC Public Health 2013, 13, S1. [CrossRef] [PubMed]

20. Siddiqui, F.; Salam, R.A.; Lassi, Z.S.; Das, J.K. The Intertwined Relationship between Malnutrition and Poverty. Front. Public Health 2020, 8, 453. [CrossRef]

21. One Health, Zero Hunger. Available online: https://www.globalhungerindex.org/issues-in-focus/2020.html (accessed on 16 February 2021).

22. How to Feed the World in 2050-An Issue Brief Prepared for the High Level Expert Forum. 2009. Available online: http: //www.fao.org/wsfs/forum2050/wsfs-forum/en/ (accessed on 17 February 2021).

23. Food and Agriculture Organization of the United Nations. An Introduction to the Basic Concepts of Food Security (FAO, Rome). Available online: http://www.fao.org/documents/card/en/c/2357d07c-b359-55d8-930a-13060cedd3e3/ (accessed on 17 February 2021).

24. Talberth, J.; Susan, L. Reviving Dormant Ethnobotany: The role of women and plant knowledge in a food secure world. In Proceedings of the 36th Annual Conference of the Society of Ethnobiology in University of North Texas, Denton, TX, USA, 15-18 May 2013. Available online: https://sustainable-economy.org/wp-content/uploads/2013/06/Reviving-DormantEthnobotany.pdf (accessed on 10 March 2021).

25. Dwivedi, S.L.; Lammerts van Bueren, E.T.; Ceccarelli, S.; Grando, S.; Upadhyaya, H.D.; Ortiz, R. Diversifying Food Systems in the Pursuit of Sustainable Food Production and Healthy Diets. Trends Plant Sci. 2017, 22, 842-856. [CrossRef] [PubMed]

26. Shaheen, S.; Ahmad, M.; Haroon, N. Diversity of Edible Wild Plants: Global Perspectives. In Edible Wild Plants: An Alternative Approach to Food Security; Springer International Publishing: Cham, Germany, 2017; pp. 59-64; ISBN 9783319630366. 
27. Ray, A.; Ray, R.; Sreevidya, E.A. How Many Wild Edible Plants Do We Eat-Their Diversity, Use, and Implications for Sustainable Food System: An Exploratory Analysis in India. Front. Sustain. Food Syst. 2020, 4, 56. [CrossRef]

28. Thakur, A.; Singh, S.; Puri, S. Exploration of Wild Edible Plants Used as Food by Gaddis-A Tribal Community of the Western Himalaya. Sci. World J. 2020, 2020, 1-6. [CrossRef] [PubMed]

29. Ashagre, M.; Asfaw, Z.; Kelbessa, E. Ethnobotanical Study of Wild Edible Plants in Burji District, Segan Area Zone of Southern Nations, Nationalities and Peoples Region (SNNPR), Ethiopia. J. Ethnobiol. Ethnomed. 2016, 12, 32. [CrossRef]

30. Duguma, H.T. Wild Edible Plant Nutritional Contribution and Consumer Perception in Ethiopia. Int. J. Food Sci. 2020, $2020,1-16$. [CrossRef]

31. Zhang, L.; Chai, Z.; Zhang, Y.; Geng, Y.; Wang, Y. Ethnobotanical Study of Traditional Edible Plants Used by the Naxi People during Droughts. J. Ethnobiol. Ethnomed. 2016, 12, 39. [CrossRef]

32. Pawera, L.; Khomsan, A.; Zuhud, E.A.; Hunter, D.; Ickowitz, A.; Polesny, Z. Wild Food Plants and Trends in Their Use: From Knowledge and Perceptions to Drivers of Change in West Sumatra, Indonesia. Foods 2020, 9, 1240. [CrossRef] [PubMed]

33. Psaroudaki, A.; Nikoloudakis, N.; Skaracis, G.; Katsiotis, A. Genetic Structure and Population Diversity of Eleven Edible Herbs of Eastern Crete. J. Biol. Res. Thessalon. 2015, 22, 7. [CrossRef]

34. Pieroni, A.; Nebel, S.; Santoro, R.F.; Heinrich, M. Food for Two Seasons: Culinary Uses of Non-Cultivated Local Vegetables and Mushrooms in a South Italian Village. Int. J. Food Sci. Nutr. 2005, 56, 245-272. [CrossRef]

35. Ghirardini, M.; Carli, M.; del Vecchio, N.; Rovati, A.; Cova, O.; Valigi, F.; Agnetti, G.; Macconi, M.; Adamo, D.; Traina, M.; et al. The Importance of a Taste. A Comparative Study on Wild Food Plant Consumption in Twenty-One Local Communities in Italy. J. Ethnobiol. Ethnomed. 2007, 3, 22. [CrossRef]

36. Pinela, J.; Carvalho, A.M.; Ferreira, I.C.F.R. Wild Edible Plants: Nutritional and Toxicological Characteristics, Retrieval Strategies and Importance for Today's Society. Food Chem. Toxicol. 2017, 110, 165-188. [CrossRef]

37. Osorio, N.W. Soil Nutrient Management in the Tropics; Universidad Nacional de Colombia: Medellin, Colombia, 2012.

38. León, J.D.; Osorio, N.W. Role of Litter Turnover in Soil Quality in Tropical Degraded Lands of Colombia. Sci. World J. 2014, 2014, 693981. [CrossRef]

39. Lamb, D.; Erskine, P.D.; Parrotta, J.A. Restoration of Degraded Tropical Forest Landscapes. Science 2005, 310, 1628-1632. [CrossRef] [PubMed]

40. Bini, C. Soil: A Precious Natural Resource. In Conservation of Natural Resources; Kudrow, N.J., Ed.; Nova Science Publishers: Hauppauge, NY, USA, 2009; pp. 1-48. ISBN 9781607411789.

41. Lal, R. Restoring Soil Quality to Mitigate Soil Degradation. Sustainability 2015, 7, 5875-5895. [CrossRef]

42. Scherr, S.J. The Future Food Security and Economic Consequences of Soil Degradation in the Developing World. In Response to Land Degradation; Bridges, M.E., Hannam, I.D., Oldeman, R.L., Penning de Vries, F.W.T., Scherr, S.J., Sombatpanit, S., Eds.; Broken Sound Plaza: Seattle, WA, USA, 2009; pp. 153-170.

43. Quarles, W. Pesticides and Honey Bee Colony Collapse Disorder. IPM Pract. 2008, 30, 1-10.

44. Quarles, W. Protecting Native Bees and Other Pollinators. Common Sense Pest Control Q. 2008, 24, 4-14.

45. Stokstad, E. Field Research on Bees Raises Concern about Low-Dose Pesticides. Science 2012, 335, 1555. [CrossRef]

46. Quarles, W. Pesticides and Honey Bee Death and Decline. IPM Pract. 2011, 33, 1-8.

47. Pollinator Health and Colony Collapse Disorder. Hearing to Review the Status of Pollinator Health Including Colony Collapse Disorder Hearing before the Subcommittee on Horticulture and Organic Agriculture of the Committee on Agriculture House of Representatives; Serial No. 110-39. 26 June 2008. Available online: https: / / www.govinfo.gov/content/pkg/CHRG-110hhrg506 79/html/CHRG-110hhrg50679.html (accessed on 13 August 2020).

48. Spivak, M.; Mader, E.; Vaughan, M.; Euliss, N.H. The Plight of the Bees. Environ. Sci. Technol. 2011, 45, 34-38. [CrossRef] [PubMed]

49. Colony Collapse Disorder and Pollinator Decline. Hearing to Review the Status of Pollinator Health Including Colony Collapse Disorder Hearing before the Subcommittee on Horticulture and Organic Agriculture of the Committee on Agriculture House of Representatives. 29 March 2007. Available online: https:/ / www.govinfo.gov/content/pkg/CHRG-110hhrg36465/html/CHRG110hhrg36465.html (accessed on 12 August 2020).

50. Schacker, M. A Spring without Bees: How Colony Collapse Disorder Has Endangered Our Food Supply; Lyons Press: Guilford, NC, USA, 2008; ISBN 9781599216003.

51. Aktar, W.; Sengupta, D.; Chowdhury, A. Impact of Pesticides Use in Agriculture: Their Benefits and Hazards. Interdiscip. Toxicol. 2009, 2, 1-12. [CrossRef] [PubMed]

52. The Conservation of Lands in Asia and the Pacific. CLASP: A Framework for Action; FAO: Rome, Italy, 1995; Available online: http:/ / www.fao.org/docrep/v9909e/v9909e02.html (accessed on 12 August 2020).

53. Bhan, S. Land Degradation and Integrated Watershed Management in India. Int. Soil Water Conserv. Res. 2013, 1, 49-57. [CrossRef]

54. Spiertz, H. Challenges for Crop Production Research in Improving Land Use, Productivity and Sustainability. Sustainability 2013, 5, 1632-1644. [CrossRef]

55. Winterbottom, R.; Reij, C.; Garrity, D.; Glover, J.; Hellums, D.; McGahuey, M.; Scherr, S. Improving Land and Water Management. Creating a Sustainable Food Future; Installment Four, Washington, Working Paper; World Resources Institute: Washington, DC, USA, 2013. Available online: https://www.wri.org/publication/improving-land-and-water-management (accessed on 6 August 2020). 
56. Gil, J.D.B.; Reidsma, P.; Giller, K.; Todman, L.; Whitmore, A.; van Ittersum, M. Sustainable Development Goal 2: Improved Targets and Indicators for Agriculture and Food Security. Ambio 2019, 48, 685-698. [CrossRef] [PubMed]

57. Altieri, M.A. Linking Ecologists and Traditional Farmers in the Search for Sustainable Agriculture. Front. Ecol. Environ. 2004, 2, 35-42. [CrossRef]

58. Barrera-Bassols, N.; Zinck, J.A. Ethnopedology: A Worldwide View on the Soil Knowledge of Local People. Geoderma 2003, 111, 171-195. [CrossRef]

59. Mikkelsen, J.H.; Langohr, R. Indigenous knowledge about soils and a sustainable crop production, a case study from the Guinea Woodland Savannah (Northern Region, Ghana). Geogr. Tidsskr. Dan. J. Geogr. 2004, 104, 13-26. [CrossRef]

60. Grzywacz, D.; Stevenson, P.C.; Mushobozi, W.L.; Belmain, S.; Wilson, K. The Use of Indigenous Ecological Resources for Pest Control in Africa. Food Secur. 2014, 6, 71-86. [CrossRef]

61. Bentley, J.W.; Thiele, G. Bibliography: Farmer Knowledge and Management of Crop Disease. Agric. Hum. Values 1999, $16,75-81$. [CrossRef]

62. Brush, S.B. Ethnoecology, Biodiversity, and Modernization in Andean Potato Agriculture. J. Ethnobiol. 1992, 12, $161-185$.

63. Brush, S.B. Farmers' Rights and the Protection of Traditional Agricultural Knowledge; CAPRi WORKING PAPER NO. 36, 1-41; International Food Policy Research Institute: Washington, DC, USA, 2005. Available online: https://www.ifpri.org/publication/ farmers-rights-andprotection-traditional-agricultural-knowledge (accessed on 10 March 2021).

64. Wolf, P.; Medin, D.L. Measuring the evolution and devolution of folk-biological knowledge. In On Biocultural Diversity: Linking Language, Knowledge and the Environment; Maffi, L., Ed.; Smithsonian Institution Press: Washington, DC, USA, 2001; pp. 212-227.

65. Turner, N.J.; Turner, K.L. "Where Our Women Used to Get the Food": Cumulative Effects and Loss of Ethnobotanical Knowledge and Practice; Case Study from Coastal British Columbia This Paper Was Submitted for the Special Issue on Ethnobotany, Inspired by the Ethnobotany Symposium Organized by Alain Cuerrier, Montreal Botanical Garden, and Held in Montreal at the 2006 Annual Meeting of the Canadian Botanical Association. Botany 2008, 86, 103-115. [CrossRef]

66. Rockström, J.; Steffen, W.; Noone, K.; Persson, Å.; Chapin, F.S.; Lambin, E.F.; Lenton, T.M.; Scheffer, M.; Folke, C.; Schellnhuber, H.J.; et al. A Safe Operating Space for Humanity. Nature 2009, 461, 472-475. [CrossRef] [PubMed]

67. Dove, M.R. The life-cycle of indigenous knowledge, and the case of natural rubber production. In Indigenous Environmental Knowledge and Its Transformations; Bicker, A., Ellen, R., Parkes, P., Eds.; Harwood Academic Publishers: Amsterdam, The Netherlands, 2000; pp. 213-251.

68. Brush, S.B. Farmers' Rights and Protection of Traditional Agricultural Knowledge. World Dev. 2007, 35, 1499-1514. [CrossRef]

69. Maldonado, J.; Bennett, T.M.B.; Chief, K.; Cochran, P.; Cozzetto, K.; Gough, B.; Redsteer, M.H.; Lynn, K.; Maynard, N.; Voggesser, G. Engagement with Indigenous Peoples and Honoring Traditional Knowledge Systems. Clim. Chang. 2016, 135, 111-126. [CrossRef]

70. Subramanian, S.M.; Pisupati, B. Traditional Knowledge in Policy and Practice: Approaches to Development and Human Well-Being; United Nations University Press: Tokyo, Japan, 2010; ISBN 9789280811919.

71. Garnatje, T.; Peñuelas, J.; Vallès, J. Ethnobotany, Phylogeny, and 'Omics' for Human Health and Food Security. Trends Plant Sci. 2017, 22, 187-191. [CrossRef]

72. Zhu, F.; Qin, C.; Tao, L.; Liu, X.; Shi, Z.; Ma, X.; Jia, J.; Tan, Y.; Cui, C.; Lin, J.; et al. Clustered Patterns of Species Origins of Nature-Derived Drugs and Clues for Future Bioprospecting. Proc. Natl. Acad. Sci. USA 2011, 108, 12943-12948. [CrossRef]

73. Hussain, M.d.S.; Rahman, M.d.A.; Fareed, S.; Ansari, S.; Ahmad, I.; Mohd, S. Current Approaches toward Production of Secondary Plant Metabolites. J. Pharm. Bioallied Sci. 2012, 4, 10. [CrossRef]

74. Ekor, M. The Growing Use of Herbal Medicines: Issues Relating to Adverse Reactions and Challenges in Monitoring Safety. Front. Pharmacol. 2014, 4, 177. [CrossRef] [PubMed]

75. Bussmann, R.W. Ethnobotany and Biodiversity Conservation. In Modern Trends in Applied Terrestrial Ecology; Ambasht, N.K., Ambasht, R.S., Eds.; Springer: Boston, MA, USA, 2002; pp. 343-360. [CrossRef]

76. Baker, J.T.; Borris, R.P.; Carté, B.; Cordell, G.A.; Soejarto, D.D.; Cragg, G.M.; Gupta, M.P.; Iwu, M.M.; Madulid, D.R.; Tyler, V.E. Natural Product Drug Discovery and Development: New Perspectives on International Collaboration. J. Nat. Prod. 1995, 58, 1325-1357. [CrossRef]

77. Farnsworth, N.R.; Akerele, O.; Bingel, A.S.; Soejarto, D.D.; Guo, Z. Medicinal plants in therapy. Bull. World Health Organ. 1985, 63, 965-981. [CrossRef]

78. Rao, K.V. Taxol and Related Taxanes. I. Taxanes of Taxus Brevifolia Bark. Pharm. Res. 1993, 10, 521-524. [CrossRef]

79. Abourashed, E.A.; El-Alfy, A.T.; Khan, I.A.; Walker, L. Ephedra in Perspective-A Current Review. Phytother. Res. 2003, 17, 703-712. [CrossRef] [PubMed]

80. Sarpras, M.; Gaur, R.; Sharma, V.; Chhapekar, S.S.; Das, J.; Kumar, A.; Yadava, S.K.; Nitin, M.; Brahma, V.; Abraham, S.K.; et al. Comparative Analysis of Fruit Metabolites and Pungency Candidate Genes Expression between Bhut Jolokia and Other Capsicum Species. PLoS ONE 2016, 11, e0167791. [CrossRef]

81. Su, X.Z.; Miller, L.H. The Discovery of Artemisinin and the Nobel Prize in Physiology or Medicine. Sci. China Life Sci. 2015, 58, 1175-1179. [CrossRef] [PubMed]

82. Alves, R.R.; Rosa, I.M. Biodiversity, Traditional Medicine and Public Health: Where Do They Meet? J. Ethnobiol. Ethnomed. 2007, 3, 14. [CrossRef] [PubMed] 
83. Uniyal, S.K.; Singh, K.; Jamwal, P.; Lal, B. Traditional Use of Medicinal Plants among the Tribal Communities of Chhota Bhangal, Western Himalaya. J. Ethnobiol. Ethnomed. 2006, 2, 14. [CrossRef] [PubMed]

84. Pan, S.Y.; Litscher, G.; Gao, S.H.; Zhou, S.F.; Yu, Z.-L.; Chen, H.Q.; Zhang, S.F.; Tang, M.-K.; Sun, J.-N.; Ko, K.-M. Historical Perspective of Traditional Indigenous Medical Practices: The Current Renaissance and Conservation of Herbal Resources. Evid. Based Complementary Altern. Med. 2014, 2014, 525340. [CrossRef]

85. Wright, R.M.; Kapfhammer, W.; Wiik, F.B. The clash of cosmographies: Indigenous societies and project collaboration-Three ethnographic cases (Kaingang, Sateré-Mawé, Baniwa). Vibrant Virtual Braz. Anthropol. 2012, 9, 382-450. [CrossRef]

86. Saslis-Lagoudakis, C.H.; Savolainen, V.; Williamson, E.M.; Forest, F.; Wagstaff, S.J.; Baral, S.R.; Watson, M.F.; Pendry, C.A.; Hawkins, J.A. Phylogenies Reveal Predictive Power of Traditional Medicine in Bioprospecting. Proc. Natl. Acad. Sci. USA 2012, 109, 15835-15840. [CrossRef] [PubMed]

87. Hawkins, J.A.; Teixidor-Toneu, I. Defining Ethnobotanical Convergence. Trends Plant Sci. 2017, 22, 639-640. [CrossRef] [PubMed]

88. Obakiro, S.B.; Kiprop, A.; Kowino, I.; Kigondu, E.; Odero, M.P.; Omara, T.; Bunalema, L. Ethnobotany, Ethnopharmacology, and Phytochemistry of Traditional Medicinal Plants Used in the Management of Symptoms of Tuberculosis in East Africa: A Systematic Review. Trop. Med. Health 2020, 48, 68. [CrossRef] [PubMed]

89. Schilmiller, A.L.; Pichersky, E.; Last, R.L. Taming the Hydra of Specialized Metabolism: How Systems Biology and Comparative Approaches Are Revolutionizing Plant Biochemistry. Curr. Opin. Plant Biol. 2012, 15, 338-344. [CrossRef]

90. Kumar, A.; Kumar, S.; Thomas, T.D.; Ramchiary, N.; Swamy, M.K.; Ahmad, I. Linking Omics Approaches to Medicinal Plants and Human Health. In Natural Bio-Active Compounds: Volume 3: Biotechnology, Bioengineering, and Molecular Approaches; Akhtar, M.S., Swamy, M.K., Eds.; Springer: Singapore, 2019; pp. 31-57. ISBN 9789811374388.

91. Sofowora, A.; Ogunbodede, E.; Onayade, A. The Role and Place of Medicinal Plants in the Strategies for Disease Prevention. Afr. J. Tradit. Complementary Altern. Med. 2013, 10, 210-229. [CrossRef]

92. Karunamoorthi, K.; Jegajeevanram, K.; Vijayalakshmi, J.; Mengistie, E. Traditional Medicinal Plants: A Source of Phytotherapeutic Modality in Resource-Constrained Health Care Settings. J. Evid. Based Complementary Altern. Med. 2013, 18, 67-74. [CrossRef]

93. Plotkin, M.J. Tales of a Shaman's Apprentice: An Ethnobotanist Searches for New Medicines in the Amazon Rain Forest; Viking Penguin: New York, NY, USA, 1993; p. 318.

94. Schipmann, U.; Leaman, D.J.; Cunningham, A.B.; Walter, S. Impact of Cultivation and Gathering of Medicinal Plants on Biodiversity: Global Trends and Issues. Acta Hortic. 2005, 31-44. [CrossRef]

95. Miththapala, S. (Ed.) Conserving Medicinal Species: Securing a Healthy Future; Ecosystems and Livelihoods Group; Asia Asian Regional Office The World Conservation Union (IUCN): Colombo, Sri Lanka, 2006; ISBN 9789558177419.

96. Bentley, R. Medicinal Plants; Domville-Fife Press: London, UK, 2010.

97. Cunningham, A.B. The role of ethnobotany and indigenous knowledge in conservation of plant genetic resources. Dinteria 1992, 23, 119-131.

98. Phillips, O.; Gentry, A.H. The Useful Plants of Tambopata, Peru: II. Additional Hypothesis Testing in Quantitative Ethnobotany. Econ. Bot. 1993, 47, 33-43. [CrossRef]

99. Phillips, O.; Gentry, A.H. The Useful Plants of Tambopata, Peru: I. Statistical Hypotheses Tests with a New Quantitative Technique. Econ. Bot. 1993, 47, 15-32. [CrossRef]

100. De Albuquerque, U.P.; de Sousa Araújo, T.A.; Ramos, M.A.; do Nascimento, V.T.; de Lucena, R.F.P.; Monteiro, J.M.; Alencar, N.L.; de Lima Araújo, E. How Ethnobotany Can Aid Biodiversity Conservation: Reflections on Investigations in the Semi-Arid Region of NE Brazil. Biodivers. Conserv. 2009, 18, 127-150. [CrossRef]

101. Peters, C.M.; Alexiades, M.; Laird, S.A. Indigenous Communities: Train Local Experts to Help Conserve Forests. Nature 2012, 481, 443. [CrossRef] [PubMed]

102. Peters, C.M. Economic Botany and Management Potential of Neotropical Seasonally Dry Forests. In Seasonally Dry Tropical Forests: Ecology and Conservation; Dirzo, R., Young, H.S., Mooney, H.A., Ceballos, G., Eds.; Island Press: Washington, DC, USA, 2011; pp. 239-257. [CrossRef]

103. Posey, D.E. Traditional knowledge, conservation and the Rain Forest Harvest. In Sustainable Harvest and Marketing of Rainforest Products; Plotkin, M.J., Famolare, L., Eds.; Island Press: Washington, DC, USA, 1992; pp. 46-50.

104. Pimbert, M.P.; Pretty, J.N. Parks, People and Professionals: Putting "Participation" into Protected Area Management"; UNRISD Discussion Paper 57. 1995. Available online: https:/ / www.unrisd.org/unrisd/website/document.nsf/(httpPublications)/FD4 5EA7929FCAECC80256B67005B66D8?OpenDocument (accessed on 10 March 2021).

105. World Health Organisation (WHO). Address of Director-General (Dr Margaret Chan) of the World Health Organization at the WHO Congress on Traditional Medicine. Available online: http://www.who.int/dg/speeches/2008/20081107/en/ (accessed on 13 August 2020). 